\title{
UJI DAYA HAMBAT ORGANISME LAUT SPONS Amphimedon sp., TERHADAP PERTUMBUHAN BAKTERI Staphylococcus aureus, Escherichia coli, DAN Jamur Candida albicans
}

\author{
Rizky Akbar Latif ${ }^{1)}$, Defny S. Wewengkang ${ }^{1)}$, Henki Rotinsulu ${ }^{1)}$ \\ ${ }^{1)}$ Program Studi Farmasi FMIPA UNSRAT Manado, 95115
}

\begin{abstract}
Sponges are marine animals that can produce bioactives that are useful as anti-virus, anti-fungal, antibiotic, anti-cancer, anti-inflammatory, and antioxidants. Amphimedon sp., sponge itself is found in the waters of Lembeh islands, the City of Bitung. This study was to determine the inhibitory activity against the microorganisms growth of Amphimedon sp., sponge, against microbes of Staphylococcus aureus, Escherichia coli, and Candida albicans. Based on the results of the study, the extracts and fractions of Amphimedon sp., sponge samples did not have microbial inhibitory activity against the test microbes of Staphylococcus aureus, Escherichia coli, and Candida albicans
\end{abstract}

Keywords : Amphimedon sp., Antimicrobial, Staphylococcus aureus, Escherichia coli, Candida albicans

\begin{abstract}
ABSTRAK
Spons merupakan hewan laut yang dapat menghasilkan bioaktif yang bermanfaat sebagai anti virus, anti jamur, antibiotik, anti kanker, anti inflamasi, dan antioksidan. Spons Amphimedon sp sendiri ditemukan didaerah perairan pulau Lembeh kota bitung. Penelitian ini yaitu untuk mengetahui aktivitas daya hambat pertumbuhan mikroorganisme dari spons Amphimedon sp., terhadap mikroba Staphylococcus aureus, Escherichia coli, dan Candida albicans. Berdasarkan hasil penelitian menunjukkan ekstrak dan fraksi sampel spons Amphimedon sp., tidak memiliki aktivitas daya hambat terhadap mikroba uji Staphylococcus aureus, Escherichia coli, dan Candida albicans
\end{abstract}

Kata kunci : Amphimedon sp., Antimikroba, Staphylococcus aureus, Escherichia coli, Candida albicans 


\section{PENDAHULUAN}

Mikroba patogen merupakan salah satu penyebab penyakit pada manusia dan makhluk hidup lainnya (Juariah et al., 2014). Berbagai penelitian menunjukkan bahwa organisme laut memiliki potensi yang sangat besar dalam menghasilkan senyawasenyawa aktif yang dapat digunakan sebagai bahan baku obat. Beberapa organisme laut yang diketahui dapat menghasilkan senyawa aktif, salah satunya adalah ascidians. Organisme ini diketahui dapat menghasilkan sejumlah besar produk laut yang bersifat alami, juga mampu menunjukkan keragaman senyawa kimia yang sangat besar (Thakur dan Muller, 2004).

$$
\text { Senyawa dengan berbagai }
$$

bioaktivitas, anatara lain: antivirus, antibakteri, antikanker, antileukimia, antiinflamasi, insektisida, dan antihelmintik telah ditemukan dari spons (Kim, 2012). Hal ini membuat spons menjadi salah satu hewan laut yang menarik untuk diteliti karena berpotensi besar untuk dikembangkan dalam bidang pengobatan salah satunya sebagai antibakteri (Abubakar et al, 2011).

$$
\text { Staphylococcus aureus adalah }
$$

bakteri kokus gram positif. Bakteri ini sering ditemukan sebagai kuman flora normal pada manusia. Bakteri Staphylococcus aureus dapat menjadi penyebab infeksi baik pada manusia maupun pada hewan. Infeksi yang disebabkan oleh Staphylococcus aureus dapat berkembang menjadi infeksi sistemik yang parah. Habitat Staphylococcus aureus biasanya ada di rongga hidung. Dari rongga hidung, Staphylococcus aureus dapat berpindah dan menyebar kekulit maupun bagian tubuh lainnya. Selain di lokasi tersebut, Koloni Staphylococcus aureus juga dapat ditemukan di tenggorokkan, usus, vagina, lipatan kulit (ketiak) dan perineum. Tetapi infeksi yang disebabkan oleh Staphylococcus aureus merupakan masalah penting di bagian kesehatan. Hal ini dikarenakan adanya beberapa kasus resistensi pada antibiotik. Selain karena resistensi, pengguna antibiotik memerlukan biaya yang belum tentu dapat dicapai oleh masyarakat umum (Rahardjo, 2017).

Escherichia coli merupakan family Enterobacteriaceae dengan ukuran panjang sel 2,0 - 6,0 $\mu \mathrm{m}$ dan lebar 1,1 - 1,5 $\mu \mathrm{m}$ dan tidak ditemukan spora. Escherichia coli termasuk bakteri gram negatif, selnya bisa terdapat tunggal, berpasangan, dan dalam rantai pendek, biasanya tidak berkapsul. Escherichia coli merupakan penghuni normal usus yang seringkali menyebabkan infeksi (Wulandari, 2010).

Candida albicans merupakan salah satu mikroorganisme yang terdapat pada mukosa mulut dapat menyebabkan stomatitis apthosa atau sariawan. Kandidiasis dapat mencegah pertumbuhannya dengan menggunakan antiseptik dan anti fungi (Melsi et al., 2011).

Spons Amphimedon sp., termasuk anggota kelas Demospongia digunakan sebagai materi penelitian. Genus ini banyak dilaporkan memiliki bahan aktif yang bermanfaat. Hasil ekstraksi spons genus Amphimedon dapat dimanfaatkan sebagai anti kanker (leukemia) (Nishi et al., 2008).

\section{METODOLOGI PENELITIAN Bentuk Penelitian}

Bentuk penelitian ini ialah eksperimen laboratorium yang akan menguji komponen yang diekstrak dari Spons 
Amphimedon sp., sebagai antimikroba yang diperoleh dari perairan Selat Lembeh.

\section{Waktu dan Tempat Penelitian}

Penelitian ini dilaksanakan pada bulan September 2018 sampai - Februari 2019. Tempat pengambilan sampel dilakukan di Perairan Selat Lembeh, Kota Bitung dan untuk preparasi sampel, pengamatan dilakukan di Laboratorium Penelitian Farmasi Lanjutan (Farmakognosi Fitokimia dan Laboratorium Mikrobiologi Farmasi) Program Studi Farmasi, Fakultas Matematika dan Ilmu Pengetahuan Alam, Universitas Sam Ratulangi

\section{Alat dan Bahan}

\section{a. Alat}

Alat yang digunakan dalam penelitian ini yaitu sarung tangan, zipper bag, gunting, kamera, wadah kaca, pisau, Erlenmeyer (Pyrex), corong pisah, timbangan analitik, gelas ukur (Pyrex), gelas kimia (Pyrex), Cawan Petri, autoklaf (autoklaf KT-30s), spatula, pinset, pembakar spritus, pipet tetes, mikro tubes, batang pengaduk, Laminar air flow (Clean Bench), rak tabung reaksi, tabung reaksi, lemari pendingin, incubator incucel (N-Biotek), cakram (Paper disc), mikropipet, digital caliper, vial, oven, jarum ose, vortex dan jas lab.

\section{b. Bahan}

Bahan-bahan yang digunakan yaitu Spons Amphimedon sp,. mikroba uji Staphylococcus aureus, Escherichia coli, dan Candida albicans, etanol 96\%, akuades, metanol, n-heksan, kloroform, nutrient broth, nutrien agar, potato dextrose agar, Kloramfenikol, kertas cakram, label, spidol permanen, tissue, aluminium foil, kertas saring, kapas.

\section{Prosedur Penpelitian Ekstraksi}

Ekstrak Spons Amphimedon sp., sebanyak $540 \mathrm{~g}$ diekstraksi dengan menggunakan cara maserasi. Sampel dipotong kecil-kecil dengan ukuran $1 \mathrm{~cm}^{2}$ lalu dimasukkan ke dalam botol dan direndam dengan larutan etanol 96\% sampai sampel terendam secara keseluruhan dan dibiarkan selama 24 jam. Sampel yang direndam disaring dengan menggunakan kertas saring menghasilkan filtrat 1 dan debris 1. Debris 1 direndam dengan larutan etanol $96 \%$ sampai sampel terendam secara keseluruhankemudian dibiarkan selama 24 jam. Sampel tersebut disaring menggunakan kertas saring menghasilkan filtrat 2 dan debris 2. Debris 2 kemudian direndam dalam larutan etanol $96 \%$ sampai sampel terendam secara keseluruhan dan dibiarkan selama 24 jam, sampel tersebut disaring menggunakan kertas saring menghasilkan filtrat 3 dan debris 3 . Filtrat 1, 2 dan 3 dicampur menjadi satu kemudian disaring, lalu dievaporasi menggunakan rotary evaporator sehingga didapat ekstrak kasar Spons Amphimedon sp., kemudian ditimbang menggunakan timbangan analitik, diperoleh ekstrak etanol sampel sebanyak 12,84 g. Selanjutnya ekstrak etanol Spons Amphimedon sp., digunakan dalam fraksinasi dan pengujian antimikroba.

\section{Fraksinasi}

Ekstrak Sebanyak 2,00 g ekstrak etanol Spons Amphimedon sp., dimasukkan ke dalam Erlenmeyer dan dilarutkan dengan metanol 80\% sebanyak $100 \mathrm{~mL}$. Setelah sampel larut, sampel dimasukkan ke dalam corong pisah dan ditambahkan pelarut nheksan sebanyak 100 mL. Sampel kemudian dikocok berulangkali dalam corong pisah hingga homogen. Sampel dibiarkan hingga membentuk lapisan metanol $(\mathrm{MeOH})$ dan lapisan n-heksan. Masing-masing lapisan metanol dan lapisan n-heksan ditampung di dalam wadah yang berbeda. Lapisan nheksan selanjutnya dievaporasi 
menggunakan oven hingga kering, lalu ditimbang dengan timbangan analitik dan diperoleh fraksi n-heksan sebanyak 0,06 g. Selanjutnya lapisan metanol ditambahkan dengan akuades $100 \mathrm{~mL}$, kemudian dipartisi dengan pelarut kloroform menggunakan perbandingan 1:1 v/v setelah itu dikocok dalam corong pisah hingga homogen. Lapisan metanol dibiarkan hingga membentuk dua lapisan yaitu lapisan metanol dan lapisan kloroform. Masingmasing lapisan metanol dan lapisan kloroform ditampung ke dalam wadah yang berbeda.Lapisan kloroform dievaporasi menggunakan oven hingga kering lalu ditimbang dengan timbangan analitik dan diperoleh fraksi kloroform sebanyak 1,1 g. Lapisan metanol yang ditampung pada wadah lain dievaporasi menggunakan rotary evaporator hingga kering lalu ditimbang dengan timbangan analitik dan diperoleh fraksi metanol sebanyak 1,7 g. Ketiga fraksi yang diperoleh akan digunakan dalam pengujian antimikroba. Rendemenrendemen ekstrak dan fraksi dihitung dengan persamaan berat hasil ekstrak/fraksi dibagikan dengan berat awal ekstrak/fraksi kemudian dikalikan dengan $100 \%$.

\section{Pembuatan Media dan Pengujian Antimikroba}

\section{Sterilisasi Alat}

Alat-alat gelas yang digunakan dalam penelitian aktivitas antimikroba ini disterilkan terlebih dahulu dengan menggunakan autoklaf pada suhu $121{ }^{\circ} \mathrm{C}$ selama 15 menit, pinset dibakar dengan pembakaran di atas api langsung dan media disterilkan di autoklaf pada suhu $121{ }^{\circ} \mathrm{C}$ selama 15 menit (Ortez, 2005).

\section{Pembuatan Media B1}

Pepton 0,5 g, beef extract 0,3 g, natrium klorida $0,3 \mathrm{~g}$ dan akuades sebanyak $100 \mathrm{ml}$ diaduk sampai homogen kemudian disterilkan dalam autoklaf pada suhu $121^{\circ} \mathrm{C}$ selama 15 menit dan setelah itu didinginkan. Setelah dingin, media cair B1 di tutup dengan aluminium foil (Dwijendra et al, 2014).

\section{Kultur Mikroba}

Mikroba yang digunakan yaitu Escherichia coli, Staphylococcus aureus dan Candida albicans. Masing-masing mikroba diambil dari biakan murni menggunakan mikropipet sebanyak $100 \mu \mathrm{L}$ dan dimasukkan ke dalam masing-masing tabung reaksi yang sudah berisi media cair B1 sebanyak $1 \mathrm{ml}$ dan kemudian ditutup menggunakan aluminium foil. Setelah itu, diinkubasi dalam inkubator pada suhu $37^{\circ} \mathrm{C}$ selama 1 x 24 Jam (Dwijendra et al, 2014).

\section{Pengujian Antimikroba \\ Pembuatan Media Uji}

Pepton 0,5 g, beef extract 0,3 g, natrium klorida $0,3 \mathrm{~g}$, agar $1,5 \mathrm{~g}$ dan akuades sebanyak $100 \mathrm{ml}$ diaduk sampai homogen kemudian disterilkan di autoklaf pada suhu $121^{\circ} \mathrm{C}$ selama 15 menit (Dwijendra et al, 2014).

\section{Pembuatan Larutan Uji}

Larutan uji dibuat dengan cara $1 \mathrm{mg}$ ekstrak kasar Spons Amphimedon sp. dilarutkan dalam $200 \mu \mathrm{L}$ metanol dan dikocok hingga homogen menggunakan vortex. Perlakuan yang sama dilakukan pada fraksi n-heksan, fraksi kloroform dan fraksi metanol (Ortez,2005).

\section{Kontrol Positif dan Kontrol Negatif}

Kontrol positif dalam pengujian aktivitas antimikroba ini menggunakan Kloramfenikol paper disc. Kontrol negatif yang digunakan dalam penelitian ini yaitu menggunakan metanol, dengan cara membuat larutan stok metanol dengan mengambil sebanyak $200 \mu \mathrm{L}$ metanol kemudian ditotolkan pada paper disc. 


\section{Pengujian Aktivitas Antimikroba}

Metode yang digunakan dalam penelitian ini yaitu metode difusi agar (disc diffusion Kirby and Bauer). Pada pengujian aktivitas antimikroba ini, cakram (paper disc) yang digunakan berukuran $6 \mathrm{~mm}$ dengan daya serap $50 \mu \mathrm{L}$ tiap cakram. Sebanyak $100 \mu \mathrm{L}$ mikroba yang telah dikultur, dipipet dan diinokulasi pada 100 $\mathrm{ml}$ media agar lalu diaduk hingga homogen dan kemudian dituangkan ke dalam cawan petri dan tunggu sampai media agar mengeras. Kemudian, larutan uji yang telah disiapkan ditotolkan pada masing-masing cakram dengan menggunakan mikropipet. Setelah agar mengeras, kertas cakram yang telah ditotolkan sampel Spons Amphimedon sp., kontrol positif dan kontrol negatif diletakkan ke dalam cawan petri dengan menggunakan pinset. Selanjutnya, cawan petri diberi label dan diinkubasi dalam inkubator pada suhu $37^{0} \mathrm{C}$ selama 1 x $24 \mathrm{Jam}$ (Ortez, 2005).

\section{Pengamatan dan Pengukuran Diameter Zona Hambat}

Pengamatan dilakukan setelah 24 jam masa inkubasi. Daerah pada sekitaran cakram menunjukkan kepekaan mikroba terhadap antibiotik atau bahan antimikroba yang digunakan sebagai bahan uji yang dinyatakan dengan diameter zona bening. Diameter zona bening diukur menggunakkan digital caliper. Kemudian zona bening yang telah diukur, dikategorikan berdasarkan pedoman Davis dan Stout (1971).

\section{HASIL DAN PEMBAHASAN Determinasi}

Determinasi Spons Amphimedon sp. dilakukan di Fakultas Matematika dan Ilmu Pengetahuan Alam Program Studi Farmasi Universitas Sam Ratulangi. Determinasi dilakukan agar mengetahui sampel yang diambil dan dilakukan pengujian adalah sampel yang sesuai yaitu spons Amphimedon spPenggunaan bahan alami sebagai zat hambat mikroorganisme adalah langkah kembali ke alam untuk memanfaatkan bahan alami. Senyawa dalam tumbuhan, mengharuskan kita untuk mengetahui senyawa kimia yang mampu memberikan efek terapi.

\section{Preparasi Sampel}

Sampel spons Amphimedon sp. yang diambil dari perairan Selat Lembeh Bitung, dipotong kecil-kecil. Hal ini bertujuan untuk memperluas permukaan yang berinteraksi dengan pelarut sehingga lebih banyak senyawa yang dapat ditarik oleh pelarut (Kristanti et al., 2008). Setelah di potong kecil-kecil sampel lalu di masukkan kedalam wadah.

\section{Ekstraksi Spons Amphimedon sp.}

Sampel spons Amphimedon sp.dilakukan ekstraksi dengan menggunakan metode maserasi dengan pelarut etanol $96 \%$ sampai sampel terendam semua selama 24 jam. Maserasi sampel dilakukan dengan pelarut $96 \%$ karena pelarut ini memiliki kemampuan menyari dengan tingkat polaritas yang lebar mulai dari senyawa polar dan non polar (Saifudin et al, 2011). Pelarut etanol $96 \%$ memiliki sifat selektif, tidak beracun, dan bersifat universal yang cocok untuk mengekstrak semua golongan senyawa metabolit sekunder (Kristianti et al., 2008) metode maserasi dipilih karena pengerjaan dan peralatan yang digunakan sederhana, mudah diusahakan, mampu menarik senyawa-senyawa yang berkhasiat, dan untuk menghindari kerusakan beberapa senyawa aktif dari spons Amphimedon sp. (Kristiani, 2014). Prinsip ekstraksi pelarut yakni dengan memisahkan dua komponen atau lebih berdasarkan perbedaan kelarutan komponen tersebut dalam pelarut yang digunakan. Proses pemisahan akan berhasil apabila bergantung pada perbedaan 
kelarutan senyawa yang akan dipisahkan dalam pelarut (Suryanto,2012).

Proses ekstraksi dilakukan perendaman selama 3x24 jam dan setiap 24 jam ekstrak disaring dan dimaserasi kembali dengan menggunakan pelarut yang baru hal ini disebut dengan remaserasi. Remaserasi bertujuan untuk mendapatkan penyarian maksimal, agar senyawa kimia didalam sampel dapat terekstrak secara menyeluruh dengan pergantian pelarut selama tiga kali menggunakan pelarut etanol.Kemudian diperoleh filtrat diuapkan menggunakan oven $40^{\circ} \mathrm{C}$ dengan tujuan agar tidak merusak senyawa bioaktif yang terdapat difiltrat apabila menggunakan suhu tinggi. Hasil dari proses ini didapat ekstrak kasar dari pelarut (Aditya et al., 2016). Didapat Massa ekstrak beserta rendemen yang dihasilkan pada proses ekstraksi ditunjukkan pada Tabel 1 .

\section{Tabel 1. Rendemen ekstrak Spons Amphimedon sp.}

\begin{tabular}{ccccc}
\hline No & Sampel & $\begin{array}{c}\text { Massa } \\
\text { Ekstrak }\end{array}$ & Rendemen & $\begin{array}{c}\text { Warna } \\
\text { Sampel }\end{array}$ \\
\hline 1 & $\begin{array}{c}\text { Ekstrak } \\
\text { Etanol }\end{array}$ & 0,54 & 2,4 & Coklat \\
\hline
\end{tabular}

\section{Fraksinasi Amphimedon sp.}

Setelah diperoleh ekstrak kering etanol dari hasil maserasi, selanjutnya dilakukan tahap fraksinasi. Metode penelitian ini menggunakan metode fraksinasi cair-cair yang dimana merupakan metode pemisahan dengan menggunakan dua cairan pelarut yang tidak saling tercampur sehingga senyawa yang memiliki sifat polar akan larut dalam pelarut polar, yang semi polar akan larut dalam pelarut semi polar, dan yang bersifat non polar akan larut kedalam pelarut non polar (Engka, 2016). Dimana pelarut yang digunakan yang memiliki sifat kepolaran yang berbeda, yaitu methanol, n- heksan dan kloroform secara berkesinambungan dengan sifat yang berbeda dimana n-heksan mewakili sifat non polar, kloroform mewakili sifat semi-polar dan methanol mewakili sifat polar (Aditya $e t$ al., 2016).Dilakukan fraksinasi untuk senyawa berdasarkan kepolaran. Masingmasing pelarut secara selektif akan memisahkan kelompok kandungan kimia tersebut. Pertama simplisia disari berturutturut dengan pelarut yang non polar, kemudian disari dengan pelarut yang berkurang polar dan terakhir dengan pelarut polar (Iswanti, 2009). Berdasarkan massa fraksi beserta rendemen yang dihasilkan dalam proses fraksinasi ditunjukkan pada Tabel 2.

\section{Tabel 2. Rendemen fraksi Spons} Amphimedon sp.

\begin{tabular}{ccccc}
\hline No & Sampel & $\begin{array}{c}\text { Massa } \\
\text { Ekstrak } \\
(\mathbf{g})\end{array}$ & $\begin{array}{c}\text { Rendemen } \\
(\%)\end{array}$ & $\begin{array}{c}\text { Warna } \\
\text { Sampel }\end{array}$ \\
\hline $\mathbf{1}$ & $\begin{array}{c}\text { Fraksi n- } \\
\text { heksan }\end{array}$ & 0,06 & $3 \%$ & $\begin{array}{c}\text { Putih } \\
\text { bening }\end{array}$ \\
$\mathbf{2}$ & $\begin{array}{c}\text { Fraksi } \\
\text { Kloroform }\end{array}$ & 1,036 & $55 \%$ & $\begin{array}{c}\text { Putih } \\
\text { keruh }\end{array}$ \\
$\mathbf{3}$ & $\begin{array}{c}\text { Fraksi } \\
\text { methanol }\end{array}$ & 1,7 & $85 \%$ & $\begin{array}{c}\text { Putih } \\
\text { susu }\end{array}$ \\
\hline
\end{tabular}

Untuk mengetahui presentasi zat yang terekstrak dari sampel maka hasil timbang dari massa ekstrak/fraksi dibagi dengan massa sampel/ekstrak dan dikalikan $100 \%$. Perbedaan nilai ini disebabkan karena perbedaan jenis pelarut yang digunakan. Dimana, pelarut yang berbeda akan melarutkan senyawa-senyawa berbeda, sehingga jumlah fraksi pelarut methanol memiliki rendemen paling tinggi. Hal ini menunjukkan bahwa dalam Spons 
Amphimedon sp., terdapat banyak senyawa yang bersifat polar.

\section{Uji Aktivitas Antimikroba Spons Amphimedon sp.}

Uji aktivitas senyawa antimikroba dari ekstrak etanol, fraksi methanol, fraksi nheksan, dan fraksi kloroform dari spons Amphimedon sp. diuji terhadap Staphylococcus aureus yang mewakili gram positif, Escherichia coli mewakili gram negatif dan Candida albicans mewakili jamur dengan dilakukan metode difusi agar. Metode difusi agar adalah dimana metode dilakukan dengan pengukuran dan pengamatan diameter zona bening yang terbentuk disekitar cakram yang berisi zat antimikroba yang diletakkan pada media agar yang sudah diinokulasi mikroba (Lalamentik, 2017). Metode difusi agar dipilih karena memiliki kelebihan yaitu jumlah zat yang digunakan mudah diatur, cepat, dan pengerjaannya sederhana (Valgas et al., 2007), dan juga untuk melihat sensitivitas berbagai jenis mikroba terhadap antimikroba pada konsentrasi tertentu (Akhyar, 2010).

Penggunaan ketiga jenis mikroba ini bertujuan untuk mengetahui apakah ekstrak/fraksi dari Spons Amphimedon sp. memiliki aktivitas daya hambat serta mengetahui spektrum yang sempit yang hanya mampu menghambat atau membunuh salah satu golongan mikroba saja, atau spektrum luas yang dimana dapat membunuh atau menghambat baik bakteri golongan gram negatif maupun golongan gram positif (Pratiwi, 2008).

Pada uji aktivitas antimikroba hasil yang diperoleh melalui pengamatan yang dilakukan selama 1x24 jam massa inkubasi dengan 3 kali pengulangan untuk masingmasing bakteri terhadap spons Amphimedon sp., tujuannya untuk lebih mengakurat hasil pengujian yang diperoleh. pada pengujian ini, daya antimikroba ditandai dengan adanya zona bening disekelilingi kertas cakram yang berukuran $\pm 6 \mathrm{~mm}$.

Tabel 3. Hasil Pengukuran Rata-rata Diameter Uji Daya Hambat dari Ekstrak dan Fraksi Spons Amphimedon sp.

\begin{tabular}{ccccccc}
\hline Mikrob & \multicolumn{7}{c}{ Rata-rata Diameter $(\mathrm{mm})$} \\
\cline { 2 - 7 } a & EE & FK & FM & FH & + & - \\
\hline & & & & & & \\
Ec & 0,0 & 0,0 & 0,0 & 0,0 & 19,1 & 0,0 \\
& 0 & 0 & 0 & 0 & 5 & 0 \\
Sa & 0,0 & 0,0 & 0,0 & 0,0 & 21,2 & 0,0 \\
& 0 & 0 & 0 & 0 & 2 & 0 \\
Ca & 0,0 & 0,0 & 0,0 & 0,0 & 20,1 & 0,0 \\
& 0 & 0 & 0 & 0 & 0 & 0 \\
\hline
\end{tabular}

Keterangan :

Ec : Escherichia coli

$\mathrm{Sa} \quad$ : Staphylococcus aureus

$\mathrm{Ca}$ : Candida albicans

EE : Ekstrak Etanol

FK : Fraksi Kloroform

FM : Fraksi Metanol

FH : Fraksi n-heksan

$+\quad$ : Kontrol Positif

- $\quad$ : Kontrol Negatif

Pada pengujian ini menunjukkan bahwa tidak adanya kepekaan antimikroba maupun antibiotik terhadap ekstrak dan fraksi Spons Amphimedon sp., kemampuan penghambatan pertumbuhan mikroba uji dipresentasikan oleh terbentuknya zona bening pada pengujian aktivitas antimikroba. Proses dilakukan 3 (tiga) kali pengulagan pada pengujian ini, dimana bertujuan agar hasil yang diperoleh lebih akurat. Symbiant yang berasosiasi dengan spons Amphimedon sp. tidak mampu menghasilkan senyawa metabolit sekunder seperti, alkaloid, terpenoid, steroid, kuinon, fenol dan sebagiannya yang dimana Senyawa-senyawa-senyawa ini sebagian besar mempunyai potensi sebagai senyawa bioaktif (Tan dan Zou, 2001). Hal ini menunjukkan secara fisiologis, proses metabolisme hewan spons dipengaruhi oleh 
beberapa faktor lingkungan seperti termperatur, kekeruhan, kekuatan arus, cahaya, salinity, serta faktor-faktor kimiawi lainnya. Sehingga jenis spons yang sama tetapi masing-masing hidup pada kondisi lingkungan yang berbeda, dapat memiliki keaktifan metabolit sekunder yang berbeda pula (Bergquist and Bedford, 1989).

Adapun kriteria kekuatan antimikroba sebagai berikut : diameter zona hambat $5 \mathrm{~mm}$ atau kurang dikategorikan lemah, zona hambat 5-10 mm dikategorikan sedang, zona hambat 10-20 mm dikategorikan kuat dan zona hambat $20 \mathrm{~mm}$ atau lebih dikategorikan sangat kuat . macam-macam kriteria ini digunakan dalam peelitian untuk menggolongkan daya hambat control dan bahan uji sampel (Davis dan Stout, 1971)

Berdasarkan pengujian ini digunakan kontrol positif dan kontrol negatif sebagai pembanding. Kontrol positif berfungsi sebagai kontrol dari zat uji, dengan membandingkan diameter daerah hambat yang terbentuk (Dwijendra, 2014). Kontrol positif yang digunakan dalam penelitian yaitu Kloramfenikol, hal ini dikarenakan kloramfenikol memiliki spektrum kerja yang luas (Rahmawati, 2015). Kontrol positif digunakan sebagai kontrol dari zat uji, dengan membandingkan diameter daerah hambat yang terbentuk (Dwijendra, 2014).Dari hasil yang diperoleh kontrol positif kloramfenikol dengan ekstrak dan fraksi sampel spons Amphimedon sp., sedangkan kontrol negatif fungsinya untuk mengetahui ada atau tidaknya pengaruh pelarut terhadap pertumbuhan mikroba uji. Kontrol negatif yang digunakan yaitu methanol, dimana digunakan sebagai untuk melarutkan larutan uji. Hal ini mengindikasikan bahwa kontrol yang digunakan tidak berpengaruh pada uji anti mikroba. Sehingga daya hambat yang terbentuk tidak berpengaruh oleh pelarut melainkan karena aktivitas senyawa yang ada pada spons laut Amphimedon sp.

\section{KESIMPULAN}

Berdasarkan hasil penelitian yang telah dilakukan dapat disimpulkan bahwa ekstrak kasar, fraksi metanol, fraksi kloroform dan fraksi n-heksan spons Amphimedon sp. tidak memiliki aktivitas antimikroba terhadap mikroba uji Staphylococcus aureus, Escherichia coli, dan Candida albicans.

\section{SARAN}

Peneliti mengharapkan dapat dilakukan identifikasi senyawa sebelum melakukan pengujian agar peneliti dapat mengetahui terlebih dahulu kandungan senyawa kimia yang terdapat pada sampel yang akan diteliti

\section{DAFTAR PUSTAKA}

Abubakar, H. Wahyudi, T. Yuhana, M. 2011. Skrining Bakteri yang Berasosiasi dengan Spons Jaspis sp., sebagai Penghasil Senyawa Antimikroba. Jurnal Ilmu Kelautan. 16 : 35-40

Aditya, A., Trianto, A., Santoso, A. 2016. Eksplorasi Jamur Simbion Pada Spons Demospongiae yang Dikoleksi dari Perairan Kupang Penghasil Bahan Antimikroba Multidrug Resistent (MDR). Jurnal ilmu Kelautan. Universitas Diponegoro.

Akhyar. 2010. Uji Daya Hambat dan Analisis KLT Bioautografi Ekstrak Akar dan Buah Bakau ( Rhizophora stylosa Griff.) Terhadap Vibrio Harveyi [skripsi]. Fakultas Farmasi 
Universitas Hasanuddin, Makassar.

Bergquist, P. R. dan Bedford, J. J. 1978. The incidence of antibacterial activity in marine Demospongiae: Systematic and geographic consideration. Mar. Biol. 46 : 215-221

Davis, W. W., T.R. Stout. 1971. Disc plate method of microbiological assay. Journal of microbiology 22: 659665.

Dwijendra, I. M. 2014. Aktivitas Antimikroba dan Karakterisasi Senyawa Fraksi Spos Lamellodysidea herbacea yang Diperoleh dari Teluk Manado [skripsi]. Program Studi Farmasi FMIPA Universitas Sam Ratulangi, Manado.

Engka, T. 2016. Aktivitas Antioksidan dan Penentuan Kandungan Total Fenolik dan Flavonoid dari Umbi Kuso Mafola (Drynariaquercifolia L.) [skripsi]. Program Studi Farmasi FMIPA Universitas Sam Ratulangi, Manado.

Iswanti, D.A. 2009. Uji Aktivitas Antimikroba Fraksi N-Heksan, Fraksi Etil Asetat, Dan Fraksi Etanol 96\% Daun Ekor Kucing (Acalypha Hispida Burm. F) Terhadap Bakteri Staphylococcus aureus ATCC 25923 Secara Dilusi [skripsi]. Fakultas Farmasi Universitas Setia Budi, Surakata.

Juariah et al. 2014. Aktivitas Antibakteri Spesies Asterias forbesii Terhadap Beberapa Jenis Bakteri Patogen.
Jurnal Perikanan Terubuk. 42(2) : $37-50$

Kristani, A. N., N.S. Aminah., M. Tanjung., B. Kurniadi. 2008. Buku Ajar Fitokimia. Unair Press, Surabaya. Lalamentik, G. 2017. Aktivitas Antibakteri Ekstrak Karang Lunak Klyxum sp. yang Diperoleh dari Teluk Manado[skripsi]. Program Studi Farmasi FMIPA Universitas Sam Ratulangi, Manado.

Nishi, T. Kubota, T. Fromont, J. Sasaki, T. Kobayashi, J. 2008. Nakinadines B-F : New Phyridine Alkaloids with a 3 -amino Acid Morety From Sponge Amphimedon sp. Journal Tetrahedron. 64 : 3127-3132

Ortez, J. H. 2005. Disk Diffusion testing in manual of antimicrobial susceptibility testing. Marie B. Coyle (Coord. Ed). American society for Microbiology, America.

Pratiwi, S. T. 2008. Mikrobiologi Farmasi. Erlangga, Jakarta.

Rahardjo, M. Koendhori, E.B Setiawan, Y. 2017. Uji Aktivitas Antibakteri Ekstrak Etanol Lidah Buaya (Aloe Vera) Terhadap Bakteri Staphylococcus aureus, Jurnal Kedokteran Syiah Kuala. 17(2) : 65-70

Rahmawati, M. 2015. Uji Aktivitas Antimikroba Ekstrak Etanol dan Air Rimpang Pacing ( Costus spiralis) Terhadap Bakteri Escherichia coli, Shigella dysenteriae, Salmonella typhimurium, Bacillus subtilis, Staphylococcus aureus Serta Fungi Candida albicans [skripsi]. Fakultas Kedokteran dan Ilmu 
Kesehatan UIN Syarif

Hidayatullah, Jakarta.

Suryanto, E. 2012. Fitokimia Antioksidan. Penerbit Putra Media Nusantara, Surabaya.

Tan, R. X. dan Zou, W. X. 2001. Endophytes: a Rich Source ofa Functional Metabolites. Natural Product Reports.18, p. 448-459

Thakur. N. L., Muller, W. E. G. 2004. Biotechnological Potential of Marine Sponge. Current Science. 86(11) : 1506-1512

Valgas, C., Souza, S. M. D., Smania, E. F. A. and Artu, S. 2007. Screening Methods to Determine Antibacterial Activity of Natural Products. Brazilian Journal of Microbiology. 38, p. 369-380.

Wulandari, 2010. Uji Aktivitas Antibakteri Ekstrak Etanol, Fraksi n-Heksan dan Etil Asetat Daun Sidaguri (Sidarhom bifolia L.) Terhadap Beberapa Bakteri [Skripsi] Universitas Sumatera Utara, Medan, 